\title{
Pengaruh Konsumsi SF dan Jus Jambu Biji Merah terhadap Perubahan Kadar Hemoglobin pada Remaja Puteri yang Mendapat Suplementasi Tablet SF di SMP Negeri 19 Kota Jambi Tahun 2019
}

\author{
Lia Artika Sari ${ }^{1 *}$, Nurmisih ${ }^{2}$, Dewi Sartika ${ }^{3}$ \\ 1,2,3 Poltekkes Kemenkes Jambi Jurusan Kebidanan, Jl. GA Siwabessy No. 42 Jambi \\ Poltekkes Kemenkes Jambi Jurusan Kebidanan, Jl. GA Siwabessy No. 42 Jambi, Indonesia, \\ "Correspondence email: liaartikasari@poltekkesjambi.ac.id
}

\begin{abstract}
Abstrak. Anemia gizi defisiensi besi merupakan anemia yang paling sering terjadi di dunia. Hasil Riskesdas menunjukkan bahwa prevalensi anemia perempuan usia $\geq 15$ tahun sebesar $22,7 \%$ sedangkan prevalensi anemia pada ibu hamil sebesar $37,1 \%$. Prevalensi anemia secara nasional untuk semua kelompok umur adalah 21,7\%. Remaja puteri rentan menderita anemia karena banyak kehilangan darah pada saat menstruasi, selain itu diperburuk oleh kurangnya asupan zat besi, kebutuhan zat besi pada remaja puteri sangat dibutuhkan untuk percepatan pertumbuhan dan perkembangan. Cakupan remaja puteri yang mendapatan tablet tambah darah sebanyak $76.2 \%$ dan yang tidak 23.8\%. Penelitian ini merupakan penelitian Quasy eksperimental Design dengan menggunakan rancangan one group pre test-post test dengan tujuan mengetahui Pengaruh Konsumsi SF dan Jus Jambu Biji Merah terhadap perubahan kadar hemoglobin pada Remaja Puteri yang mendapat Suplementasi Tablet SF di SMP Negeri 19 Kota Jambi tahun 2019. Pengambilan sampel dalam penelitian adalah Simple Random Sampling sebanyak 74 siswi. Data diperoleh dari hasil pemeriksaan kadar Hb Remaja puteri. Analisis yang digunakan adalah univariat dan bivariat. Uji statistik yang digunakan adalah uji T berpasangan ( $t$-paired test). Nilai rata-rata kadar hemoglobin pada Remaja Puteri sebelum mengkonsumsi SF dan jus jambu biji merah di SMP 19 Kota Jambi Tahun 2019 adalah $11.94 \mathrm{~g} / \mathrm{dl}$ dan Nilai rata- rata kadar hemoglobin pada Remaja Puteri sesudah mengkonsumsi SF dan jambu biji merah di SMP 19 Kota Jambi Tahun 2019 adalah 13.15 g/dl. Hasil uji statistic Ada pengaruh mengkonsumsi SF dan jus jambu biji terhadap kadar hemoglobin remaja puteri di SMP 19 Kota Jambi Tahun 2019 dengan nilai sig (2-tailed) hitung $0.000<0.05$. Dari hasil penelitian dapat disimpulkan bahwa mengkonsumsi SF bersamaan dengan jus jambu biji dapat meningkatkan kadar HB. Saran bagi tenaga kesehatan terutama bidan agar dapat memberikan pelayanan terkait pengelolaan anemia pada remaja putri siswa Sekolah Menengah Atas dengan melakukan pencegahan melalui penyuluhan.
\end{abstract}

Kata kunci: suplementasi tablet SF; jus jambu biji merah; kadar hemoglobin

Abstract. Iron deficiency nutritional anemia is the most common anemia in the world. Riskesdas results showed that the prevalence of anemia of women $\geq 15$ years old amounted to $22.7 \%$ while the prevalence of anemia in pregnant women was $37.1 \%$. The prevalence of anemia nationally for all age groups is $21.7 \%$. Young women are prone to anemia due to a lot of blood loss during menstruation, in addition to being exacerbated by a lack of iron intake, the need for iron in young women is urgently needed for accelerated growth and development. Coverage of young women who received blood-added tablets was $76.2 \%$ and that was not 23.8\%. This research is an experimental Quasy Design study using the design of one group pre test-post test with the aim of knowing the influence of SF Consumption and Red Seed Guava Juice on changes in hemoglobin levels in Young Women who received SF Tablet Supplementation at SMP Negeri 19 Jambi City in 2019. Sampling in the study was Simple Random sampling as many as 74 students. The data was obtained from the results of the examination of the level of Hb Young women. The analysis used is univariate and bivariate. The statistical test used is the t-paired test. The average value of hemoglobin levels in Young Women before consuming SF and red seed guava juice in SMP 19 Jambi City in 2019 is $11.94 \mathrm{~g} / \mathrm{dl}$ and the average value of hemoglobin in Young Women after consuming SF and guava in SMP 19 Jambi City year 2019 is $13.15 \mathrm{~g} / \mathrm{dl}$. Statistical test results There is an influence of consuming SF and guava juice on the hemoglobin levels of young women in Junior High School 19 Jambi City year 2019 with sig value (2-tailed) count $0.000<0.05$. From the results of the study can be concluded that consuming $S F$ in conjunction with guava juice can increase $H B$ levels. Advice for health workers, especially midwives, to provide services related to the management of anemia in young women of high school students by doing prevention through counseling.

Keywords: supplementation of SF tablets; guava juice; hemoglobin levels

\section{PENDAHULUAN}

Salah satu masalah yang dihadapi remaja Indonesia adalah masalah gizi mikronutrien, yakni sekitar $12 \%$ remaja laki-laki dan $23 \%$ remaja perempuan mengalami anemia, yang sebagian besar diakibatkan kekurangan zat besi (anemia defisiensi besi). Anemia dikalangan remaja perempuan lebih tinggi dibandingkan remaja laki-laki. Anemia pada remaja berdampak buruk terhadap penurunan imunitas, konsentrasi, prestasi belajar, kebugaran remaja dan produktivitas. Selain itu, secara khusus anemia yang dialami remaja putri akan berdampak lebih serius, mengingat mereka adalah para calon ibu yang akan hamil dan melahirkan seorang bayi, sehingga memperbesar resiko kematian ibu melahirkan, bayi lahir 
prematur dan berat bayi lahir rendah (Kemenkes RI, 2018).

Riskesdas (2013) menunjukkan bahwa prevalensi anemia perempuan usia $\geq 15$ tahun sebesar $22,7 \%$ sedangkan prevalensi anemia pada ibu hamil sebesar $37,1 \%$. Prevalensi anemia secara nasional untuk semua kelompok umur adalah 21,7\%. Anemia dapat disebabkan berbagai hal antara lain defisiensi zat besi, defisiensi asam folat, penyakit infeksi, faktor bawaan dan perdarahan. Di negara sedang berkembang $40 \%$ anemia disebabkan karena defisiensi zat besi yang dikenal dengan istilah anemia gizi besi. Remaja putri (rematri) rentan menderita anemia karena banyak kehilangan darah pada saat menstruasi, selain itu diperburuk oleh kurangnya asupan zat besi, dimana zat besi pada rematri sangat dibutuhkan untuk percepatan pertumbuhan dan perkembangan.

Anemia adalah suatu kondisi tubuh dimana kadar hemoglobin $(\mathrm{Hb})$ dalam darah lebih rendah dari normal (WHO, 2011). Hemoglobin adalah salah satu komponen dalam sel darah merah/eritrosit yang berfungsi untuk mengikat oksigen dan menghantarkannya ke seluruh sel jaringan tubuh. Oksigen diperlukan oleh jaringan tubuh untuk melakukan fungsinya. Kekurangan oksigen dalam jaringan otak dan otot akan menyebabkan gejala antara lain kurangnya konsentrasi dan kurang bugar dalam melakukan aktivitas (Kemenkes RI, 2016).

Data dinas kesehatan Kota Jambi menunjukkan bahwa jumlah penduduk usia remaja sebanyak 103.053 orang pada tahun 2016, yang terdiri dari 51.166 orang laki-laki dan 51.887 orang perempuan. Tahun 2018 didapatkan jumlah remaja putri yang menderita anemia sebanyak 1169 (2,25\%) dari jumlah keseluruhan. Dibandingkan dengan tahun 2016 remaja putri yang menderita anemia hanya sebanyak $395(1,03 \%)$ hal ini masih belum terlihat adanya penurunan kejadian anemia pada remaja putri di kota jambi.

Suplementasi Tablet Tambah Darah (TTD) pada rematri dan WUS merupakan salah satu upaya pemerintah Indonesia untuk memenuhi asupan zat besi. TTD program diberikan kepada remaja putri usia 12-18 tahun di sekolah menengah (SMP/SMA/Sederajat) dengan frekuensi 1 tablet seminggu satu kali sepanjang tahun. Selain itu untuk meningkatkan penyerapan zat besi dalam usus, sebaiknya mengkonsumsi makanan kaya sumber vitamin $\mathrm{C}$ seperti jeruk dan jambu dan menghindari makanan yang banyak mengandung zat yang dapat menghambat penyerapan zat besi dalam usus dalam jangka panjang dan pendek seperti tanin (dalam teh hitam,kopi), kalsium, fosfor, serat dan fitat (bijibijian). Tanin dan fitat mengikat dan menghambat penyerapan besi dari makanan (Kemenkes, 2016).

Haninda (dalam Yusnaini, 2014) menerangkan bahwa penyerapan zat besi sangat dipengaruhi oleh adanya vitamin $\mathrm{C}$ dalam tubuh remaja. Vitamin $\mathrm{C}$ dapat membantu mereduksi besi ferri $\left(\mathrm{Fe}^{3+}\right)$ menjadi fero $\left(\mathrm{Fe}^{2+}\right)$ dalam usus halus sehingga mudah di absorpsi tubuh, proses reduksi tersebut semakin besar jika $\mathrm{pH}$ didalam lambung semakin asam. Vitamin C dapat meningkatkan $\mathrm{pH}$ didalam lambung sehingga dapat meningkatkan proses penyerapan zat besi hingga $30 \%$. Kandungan vitamin $\mathrm{C}$ yang paling tinggi terdapat didalam buah jambu biji. Dalam bahasa latin jambu biji dikenal dengan sebutan psidium guajava, dan dalam bahasa inggris disebut guava. Kandungan vitamin $\mathrm{C}$ didalam jambu biji tinggi dari buah jeruk, dalam 100 gram buah jambu biji ini mengandung 183,5 mg vitamin C, sedangkan pada 100 gram buah jeruk terkandung 50$70 \mathrm{mg}$ vitamin $\mathrm{C}$.

Masa remaja atau pubertas adalah usia antara 10 sampai 19 tahun dan merupakan masa peralihan dari masa kanak-kanak menjadi dewasa. Peristiwa terpenting yang terjadi pada gadis remaja adalah datangnya haid pertama yang dinamakan menarche. Secara tradisi, menarche dianggap sebagai tanda kedewasaan (Sibagariang, EE, 2016)

Remaja didefinisikan sebagai masa peralihan dari masa anak-anak ke masa dewasa. Istilah ini menunjuk masa awal dari awal pubertas sampai tercapainya kematangan, biasanya mulai dari usia 14 pada pria dan usia 12 pada wanita. Batasan remaja dalam hal ini adalah usia 10 tahun sampai dengan 19 tahun menurut klasifikasi World Health Organization (WHO, 2011).

Kata remaja berasal dari bahasa latin yaitu adolescere (kata bendanya, adolescentia yang berarti remaja) yang berarti "tumbuh atau tumbuh menjadi dewasa. Istilah adolescene mempunyai arti yang cukup luas, mencakup kematangan mental, emosional, sosial dan fisik (Sibagariang, EE, 2016).

Anemia adalah suatu kondisi tubuh dimana kadar hemoglobin $(\mathrm{Hb})$ dalam darah lebih rendah dari normal (WHO, 2011). Hemoglobin adalah salah satu komponen dalam sel darah merah/eritrosit yang berfungsi untuk mengikat oksigen dan menghantarkannya ke seluruh sel jaringan tubuh.

Oksigen diperlukan oleh jaringan tubuh untuk melakukan fungsinya. Kekurangan oksigen dalam jaringan otak dan otot akan menyebabkan gejala antara lain kurangnya konsentrasi dan kurang bugar dalam melakukan aktivitas. Hemoglobin dibentuk dari gabungan protein dan zat besi dan membentuk sel darah merah/eritrosit. Anemia merupakan suatu gejala yang harus dicari penyebabnya dan penanggulangannya dilakukan sesuai dengan penyebabnya (Kemenkes RI, 2016).

Anemia adalah suatu kondisi dimana berkurangnya sel darah merah (eritrosit) dalam sirkulasi darah atau masa hemoglobin sehingga tidak mampu memenuhi fungsi sebagai pembawa oksigen keseluruh jaringan. Anemia juga dapat diartikan sebagai kurang nya kualitas maupun kuantitas sel darah yang membawa oksigen disekitar tubuh dalam bentuk hemoglobin. Hal ini akan menimbulkan pengurangan dalam kapasitas sel darah merah untuk membawa oksigen (Pratiwi, 2015). 
Anemia terjadi ketika tubuh tidak memiliki sel darah merah yang cukup kuat dan sehat untuk membawa oksigen ke seluruh tubuh. Pada kondisi ini, sel darah merah tidak cukup mengandung hemoglobin, yakni protein yang memberikan warna merah pada darah, atau bisa juga disebut dengan protein pembawa oksigen ke seluruh bagian tubuh (Sibagariang, EE, 2016).

Defisiensi $\mathrm{Fe}$ terjadi saat jumlah $\mathrm{Fe}$ yang diarbsorpsi tidak memadai untuk memenuhi kebutuhan tubuh. Hal ini disebabkan oleh rendahnya intake $\mathrm{Fe}$, penurunan bioavailabilitas $\mathrm{Fe}$ dalam tubuh, peningkatan kebutuhan $\mathrm{Fe}$ karena perubahan fisiologi seperti kehamilan, dan proses pertumbuhan.

Defisiensi $\mathrm{Fe}$ menunjukkan terjadinya kondisi penipisan cadangan $\mathrm{Fe}$ dalam tubuh yang dibuktikan adanya penurunan level serum ferritin, selanjutnya terjadi peningkatan absorpsi Fe akibat menurunnya level $\mathrm{Fe}$ tubuh. Manifesti keadaan ini menimbulkan eritropoiesis defisiensi Fe (defisiensi Fe tanpa anemia), cadangan $\mathrm{Fe}$ menipis dan produksi $\mathrm{Hb}$ teganggu. Meskipun konsentrasi $\mathrm{Hb}$ di atas cut off point kategori anemia, namun terjadi pengurangan transferrin saturasi yaitu jumlah suplai Fe ke sumsum tulang tidak cukup, meningkatnya konsentrasi eritrosit protoporfirin karena kekurangan $\mathrm{Fe}$ untuk membentuk Hb. Di akhir tahapan defisiensi $\mathrm{Fe}$, anemia ditandai dengan konsentrasi $\mathrm{Hb}$ atau hematoktrit di bawah range normal.

Anemia defisiensi Fe terjadi pada tahap anemia tingkat berat (severe) yang berakibat pada rendahnya kemampuan tubuh memelihara suhu, bahkan dapat mengancam kematian. (Dapartemen gizi dan kesehatan masyarakat, 2014).
Anemia gizi besi berat ditandai oleh sel darah merah yang kecil (mikrositosis) dan nilai hemoglobin rendah (hipokromia). Oleh sebab itu, anemia gizi besi dinamakan anemia hipokromik mikrositik. Kekurangan besi pada umumnya menyebabkan pucat, rasa lemah, letih, pusing, kurang nafsu makan, menurunnya kebugaran tubuh, menurunnya kemampuan kerja, menurunnya kekebalan tubuh dan gangguan penyembuhan luka (Almatsier, 2009).

Adalah penyakit yang ditandai dengan penurunan jumlah SDM (sel darah merah) dan hipokrom makrositik. Umumnya terkait dengan anemia defisiensi zat besi, jarang dijumpai kasus anemia megaloblastik saja. Anemia megaloblastik berhubungan dengan kurangnya sayuran segar atau protein hewani dalam diet (Morgan, 2009).

Anemia pernisiosa disebabkan kekurangan faktor instrik pada asam lambung, yang diperlukan untuk absorpsi vitamin B12 dari makanan, karena B12 tidak dapat diabsorpsi, SDM tidak matang dengan normal (Morgan, 2009).

Penegakan diagnosis anemia dilakukan dengan pemeriksaan laboratorium kadar hemoglobin dalam darah dengan menggunakan metode cyanmethemoglobin (WHO, 2001). Hal ini sesuai dengan Permenkes Nomor 37 Tahun 2012 tentang Penyelenggaraan Laboratorium Pusat Kesehatan Masyarakat. Rematri dan WUS menderita anemia bila kadar hemoglobin darah menunjukkan nilai kurang dari 12 g/Dl (Kemenkes RI,2016).

Tabel 1. Klasifikasi Anemia menurut Kelompok Umur

\begin{tabular}{|c|c|c|c|c|}
\hline \multirow[t]{2}{*}{ Populasi } & \multirow{2}{*}{$\begin{array}{c}\text { Non Anemia } \\
(\mathrm{g} / \mathrm{dL})\end{array}$} & \multicolumn{3}{|c|}{ Anemia (g/dL) } \\
\hline & & Ringan & Sedang & Berat \\
\hline Anak $6-59$ bulan & 11 & $10.0-10.9$ & $7.0-9.0$ & $<7.0$ \\
\hline Anak $5-11$ bulan & 11,5 & $11.0-11.4$ & $8.0-10.9$ & $<8.0$ \\
\hline Anak $12-14$ bulan & 12 & $11.0-11.9$ & $8.0-10.9$ & $<8.0$ \\
\hline Perempuan tidak hamil ( $\geq 15$ tahun) & 12 & $11.0-11.9$ & $8.0-10.9$ & $<8.0$ \\
\hline Ibu hamil & 11 & $10.0-10.9$ & $7.0-9.9$ & $<7.0$ \\
\hline Laki - laki $\geq 15$ tahun & 13 & $11.0-12.9$ & $8.0-10.9$ & $<8.0$ \\
\hline
\end{tabular}

Sumber : WHO, 2011

Remaja putri lebih banyak memerlukan zat besi untuk menggantikan zat besi yang hilang saat haid. Beberapa penelitian telah membuktikan bahwa jumlah darah yang hilang selama satu periode haid berkisaran antara 20-25 cc, maka kehilangan zat besi berkisar sebesar 12,5-15 mg/bulan atau kira-kira 0,4-0,5 mg/hari dan bila ditambah dengan kehilangan basal jumlah total zat besi yang hilang sebesar $1,25 \mathrm{mg}$ per hari. Apabila darah yang keluar selama haid sangat banyak akan terjadi anemia besi (Dieny FF, 2014).

Diduga 10 persen wanita mengeluarkan darah 27 $\mathrm{ml}$ setiap siklus menstruasi 28 hari. Diduga 10 persen wanita kehilangan darah lebih dari $80 \mathrm{ml}$ per bulan.
Banyaknya darah yang keluar berperan pada kejadian anemia karena wanita tidak mempunyai persediaan $\mathrm{Fe}$ yang cukup dan absorpsi Fe ke dalam tubuh tidak dapat menggantikan hilangnya $\mathrm{Fe}$ saat menstruasi (Dapartemen gizi dan kesehatan masyarakat, 2014).

Penyebab utama anemia besi adalah inadekuat asupan zat besi yang berasal dari makanan. Pada umumnya remaja putri lebih banyak mengkonsumsi makanan nabati yang kandungan zat besinya sedikit, dibandingkan dengan makanan hewani dan sering melakukan diet pengurangan makan karena ingin langsing, sehingga kebutuhan zat besi tidak terpenuhi (Dieny FF, 2014). 
Besi yang terdapat didalam tubuh berasal dari tiga sumber yaitu besi yang diperoleh dari perusakan sel darah merah (hemolisis), besi yang diambil dari penyimpanan dalam badan dan besi yang diserap dari saluran pencernaan. Pada saluran pencernaan, besi di reduksi dari bentuk ferri ${ }^{3+}$ menjadi ferro ${ }^{2+}$ yang lebih mudah diserap. Proses reduksi dibantu oleh vitamin $\mathrm{C}$ dan asam amino. Besi di serap di usus halus dengan bantuan tranferin dan feritin (Cakrawati, 2012).

Beberapa bagian dari otak mempunyai kadar besi tinggi yang diperoleh dari transpor besi yang dipengaruhi oleh resptor transferin. Kadar besi dalam darah meningkat selama pertumbuhan hingga remaja. Defisiensi besi berpengaruh negatif terhadap fungsi otak, terutama fungsi neutrotransmitter akibatnya kepekaan reseptor syarap dopamin berkurang dan akhirnya hilang sehingga daya konsentrasi, daya ingat dan kemampuan belajar terganggu, ambang batas rasa sakit meningkat, fungsi kelenjar tiroid dan kemampuan mengatur suhu tubuh menurun (Cakrawati, 2012).

Tanda dan gejala pada penderita anemia antara lain wajah terlihat pucat, kelopak mata, bibir, lidah, kulit dan telapak tangan menjadi pucat, terlihat gelisah, irama jantung cepat, dan nafsu makan berkurang. Gejala umum anemia timbul karena iskemia organ target serta akibat mekanisme kompensasi tubuh terhadap penurunan hemoglobin. Gejala ini muncul pada setiap kasus anemia setelah penurunan hemoglobin sampai kadar tertentu $(\mathrm{Hb}<7 \mathrm{~g} / \mathrm{dL})$. Gejala yang umum dialami oleh penderita anemia antara lain : lemah, letih, lesu, lelah dan lunglai, pusing, mata berkunang - kunang, sesak napas telinga mendenging dan kaki terasa dingin (Dieny FF, 2014).

Gejala anemia karena defisiensi zat besi bergantung pada kecepatan terjadinya anemia pada diri seseorang. Gejalanya dapat berkaitan dengan kecepatan penurunan kadar hemoglobin. Karena penurunan kadar hemoglobin akan mempengaruhi kapasitas membawa oksigen maka setiap aktivitas fisik pada anemia karena defisiensi zat besi akan menimbulkan keluhan sesak nafas. Pada awalnya, sebagian besar pasien mengeluhkan rasa mudah lelah dan mengantuk yang semakin bertambah. Keluhan lain lebih jarang dijumpai adalah sakit kepala, tinitus dan gangguan cita rasa. Kadangkala antara kadar hemoglobin dan gejala anemia terdapat korelasi yang buruk. Dengan semakin meningkatnya intensitas defisiensi, pasien akan memperlihatkan gejala pucat pada konjungtiva, lidah, dasar kuku, dan palatum mole (Gibney, 2008).

Di beberapa negara lain seperti: India, Bangladesh, dan Vietnam, pemberian TTD dilakukan 1 kali seminggu dan hal ini berhasil menurunkan prevalensi anemia di negara tersebut. Berdasarkan penelitian di Indonesia dan di beberapa negara lain tersebut, maka pemerintah menetapkan kebijakan program pemberian TTD pada rematri dan WUS dilakukan setiap 1 kali seminggu dan sesuai dengan
Permenkes yang berlaku. Pemberian TTD untuk rematri dan WUS diberikan secara blanket approach (Kemenkes RI, 2016).

Tubuh dapat menyimpan hingga $1.500 \mathrm{mg}$ vitamin $\mathrm{C}$ bila konsumsi mencapai $100 \mathrm{mg}$ sehari. Jumlah ini dapat mencegah terjadinya skorbut selama tiga bulan. Tanda-tanda skorbut akan terjadi bila persediaan tinggal $300 \mathrm{mg}$. Konsumsi melebihi taraf kejenuhan berbagai jaringan dikeluarkan melalui urin dalam bentuk asam oksalat. Pada konsumsi melebihi $100 \mathrm{mg}$ sehari kelebihan akan dikeluarkan sebagai asam askorbat atau sebagai karbondioksida melalui pernapasan. Walaupun tubuh mengandung sedikit vitamin $\mathrm{C}$, sebagian tetap akan dikeluarkan. Makanan yang tinggi dalam seng atau pektin dapat mengurangi absorpsi sedangkan zat-zat di dalam ekstrak jeruk dapat meningkatkan absorpsi (Almatsier, 2009)

Di samping itu vitamin $\mathrm{C}$ membentuk gugus besiaskorbat yang tetap larut pada $\mathrm{pH}$ lebih tinggi dalam duodenum. Oleh karena itu, sangat dianjurkan memakan makanan sumber vitamin $C$ tiap kali makan. Vitamin C dalam jumlah cukup dapat melawan sebagian pengaruh faktor-faktor yang menghambat penyerapan besi (Almatsier, 2009).

Haninda (dalam yusnaini, 2014) menerangkan bahwa kandungan vitamin $\mathrm{C}$ yang paling tinggi terdapat didalam buah jambu biji. Dalam bahasa latin jambu biji dikenal dengan sebutan psidium guajava, dan dalam bahasa inggris disebut guava. Kandungan vitamin C didalam jambu biji tinggi dari buah jeruk, dalam 100 gram buah jambu biji ini mengandung 183,5 mg vitamin $\mathrm{C}$, sedangkan pada 100 gram buah jeruk terkandung 50$70 \mathrm{mg}$ vitamin C.

Kandungan vitamin $\mathrm{C}$ pada jambu biji setara dengan enam kali kandungan vitamin $\mathrm{C}$ pada jeruk, 10 kali kandungan vitamin $\mathrm{C}$ pada pepaya, 17 kali kandungan vitamin $\mathrm{C}$ pada jambu air, dan 30 kali kandungan vitamin $\mathrm{C}$ pada buah pisang. Dengan memakan satu buah jambu biji per hari (estimasi rata rata berat jambu biji per buah 150-250g), dapat mencukupi kebutuhan harian untuk vitamin $C$, vitamin A, niacin, asam folat, serta fosfor (Hadiati, 2015).

Jambu merupakan buah sebagai sumber vitamin A dan kaya dengan vitamin C. Semua buah-buahan mempunyai kandungan vitamin $\mathrm{C}$, namun buah jambu mempunyai kandungan vitamin $\mathrm{C}$ tertinggi dibandingkan buah lainnya. Vitamin $\mathrm{C}$ didalam jambu biji memiliki fungsi menjaga pembuluh kapiler, mencegah anemia, sariawan, gusi bengkak, dan berdarah. Vitamin $\mathrm{C}$ dapat membantu penyerapan besi, dan menghambat produksi nitrosamin yang merupakan pemicu kanker (Afrianti, 2010).

\section{METODE}

\section{Tempat dan Waktu Penelitian}

Penelitian ini dilaksanakan pada SMP Negeri 19

Kota Jambi. Penentuan lokasi penelitian didasarkan atas 
pertimbangan bahwa berdasarkan data yang didapat dari Dinas Kesehatan Provinsi Jambi angka anemia pada remaja dengan usia 10-14 tahun tertinggi terdapat di Puskesmas Aur Duri, danSMP Negeri 19 Kota Jambi merupakan salah satu sekolah menengah pertama yang termasuk didalam wilayah kerja Puskesmas Aur Duri. Adapun waktu penelitian adalah bulan Mei sampai Juni 2019.

\section{Populasi dan Sampel \\ Populasi}

Populasi adalah keseluruhan sesuatu yang karakteristiknya mungkin diselidiki/diteliti (Surahman, 2016). Populasi dalam penelitian ini adalah seluruh siswi kelas VIII SMP Negeri 19 Kota Jambi sebesar 155 siswi.

\section{Sampel}

Sampel adalah bagian dari populasi yang menjadi objek penelitian (Surahman, 2016).Tehnik pengambilan sampel pada penelitian ini adalah purposive sampling, merupakan tehnik pengambilan sampel yang dilakukan atas dasar pertimbangan peneliti semata yang menganggap bahwa unsur-unsur yang dikehendaki telah ada dalam anggota sampel yang diambil.

Adapun syarat syarat yang harus dipenuhi dalam pengambilan sampel ini yaitu:

a. Pengambilan sampel harus atas ciri-ciri, sifat-sifat atau karakteristik tertentu, yang merupakan ciri-ciri pokok populasi

b. Subjek yang diambil sebagai sampel benar-benar merupakan subjek yang paling banyak mengandung ciri-ciri yang terdapat pada populasi

\section{Pengumpulan Data}

\section{Metode Pengumpulan Data}

a. Data primer

Dalam penelitian ini peneliti menggunakan data primer meliputi :

1) Konsumsi suplementasi tabletbesi

2) Konsumsi suplementasi tablet besi dan vitaminC

3) Pemeriksaan statushemoglobin dengan menggunakan alat Easy Touch

b. Instrumen penelitian dan cara penelitian

Instrumen penelitian yang digunakan adalah lembar observasi, Stik HB dan Easy Touch HB.

\section{Pengolahan Data}

\section{a. Editing}

Merupakan kegiatan untuk melakukan pemeriksaan, pengecekan, atau koreksi, pengeditan dilakukan karena kemungkinan data yang masuk tidak memenuhi syarat atau tidak sesuai dengan kebutuhan. Kesalahan data dapat dihilangkan dengan cara membuang kuesioner yang berisi data tidak memenuhi syarat untuk dianalisis.

b. Coding

Adalah kegiatan merubah data berbentuk huruf pada kuesioner menjadi bentuk angka/ bilangan dalam upaya memudahkan pengolahan data/ analisis data di komputer.

c. Processing

Setelah semua kuesioner terisi penuh dan benar serta telah dinkoding memasukkan/entry data ke dalam komputer adalah pengetikan kode angka dari jawaban responden pada kuesioner kedalam program pengolahan data di komputer.

d. Cleaning data

Adalah pemeriksaan kembali data hasil entry data pada komputer agar terhindar dari ketidaksesuaian antara data computer dan coding kuesioner.

e. Entry data

yaitu kegiatan memasukkan data yang telah didapat ke dalam program komputer yang telahditetapkan (Surahman, 2016).

\section{Analisis Data}

a. Analisis Univariat

Analisis univariat dilakukan terhadap tiap variabel dari hasil penelitian. Pada umumnya dalam analisis ini hanya menghasilkan distribusi dan presentase dari tiap variabel. Untuk menggambarkan karakteristik sampel, digunakan tabel distribusi frekuensi variabel bebas yang terdiri dari pengaruh pemberian SF dan jus jambu biji , dan tabel distribusi frekuensi variabel terikat yaitu peningkatan kadar hemoglobin remaja putri anemia.

b. Analisis Bivariat

Analisis bivariat dilakukan terhadap dua variabel yang diduga berkorelasi. Analisis bivariat yang dilakukan untuk mengetahui pengaruh pengaruh pemberian SF dan jus jambu biji terhadap peningkatan kadar hemoglobin remaja putri anemia kelas IX SMP Negeri 19 Kota Jambi. Uji statistik yang digunakan uji $\mathrm{T}$ berpasangan.

\section{HASIL DAN PEMBAHASAN}

\section{Analisis Univariat}

Gambaran pemberian SF dan jus jambu biji merah terhadap peningkatan $\mathrm{HB}$ pada remaja puteri di SMP negeri 19 Kota Jambi tahun 2019

Berdasarkan hasil penelitian diketahui distribusi kadar hemoglobin sebelum intervensi konsumsi SF dan Jus jambu biji merah pada remaja putri SMP negeri 19 Kota Jambi tahun 2019 dapat dilihat pada tabel 2.

Tabel 2. Distribusi Responden Berdasarkan Kadar Hemoglobin Sebelum konsumsi SF dan jus Jambu Biji Merah SMP negeri 19 Kota Jambi tahun 2019 n=74

\begin{tabular}{cccc}
\hline No & Kadar Hb (g/d) & \multicolumn{2}{c}{ Distribusi Frekuensi } \\
\cline { 3 - 4 } & & f & $\mathbf{( \% )}$ \\
\hline 1 & 9.1 & 1 & 1.4 \\
2 & 10.2 & 6 & 8.1 \\
3 & 10.3 & 1 & 1.4 \\
4 & 10.4 & 2 & 2.7
\end{tabular}


Lia Artika Sari et al, Pengaruh Konsumsi SF dan Jus Jambu Biji Merah terhadap Perubahan Kadar Hemoglobin pada Remaja Puteri yang Mendapat Suplementasi Tablet SF di SMP Negeri 19 Kota Jambi Tahun 2019

\begin{tabular}{crrr}
5 & 10.6 & 2 & 2.7 \\
6 & 11.1 & 4 & 5.4 \\
7 & 11.2 & 1 & 1.4 \\
8 & 11.3 & 4 & 1.4 \\
9 & 11.4 & 4 & 5.4 \\
10 & 11.5 & 3 & 5.4 \\
11 & 11.6 & 2 & 4.1 \\
12 & 11.7 & 1 & 2.7 \\
13 & 11.8 & 1 & 1.4 \\
14 & 11.9 & 2 & 1.4 \\
15 & 12.0 & 5 & 2.7 \\
16 & 12.1 & 1 & 6.8 \\
17 & 12.2 & 1 & 1.4 \\
18 & 12.3 & 8 & 1.4 \\
19 & 12.4 & 4 & 10.8 \\
20 & 12.5 & 3 & 5.4 \\
21 & 12.6 & 3 & 4.1 \\
22 & 12.7 & 1 & 4.1 \\
23 & 12.8 & 1 & 1.4 \\
24 & 12.9 & 2 & 1.4 \\
25 & 13.1 & 3 & 2.7 \\
26 & 13.2 & 5 & 4.1 \\
27 & 13.4 & 1 & 6.8 \\
28 & 13.5 & 1 & 1.4 \\
29 & 14.2 & & 1.4 \\
& Jumlah & & \\
\hline & Rata-rata & & 11.94 \\
\hline
\end{tabular}

Berdasarkan tabel diatas kadar hemoglobin sebelum konsumsi jus guava paling rendah yaitu $9.1 \mathrm{~g} / \mathrm{dl}$ dan tertinggi $14.2 \mathrm{~g} / \mathrm{dl}$. Nilai rata-rata kadar hemoglobin remaja puteri sebelum diberikan jus guava adalah 11.94 $\mathrm{g} / \mathrm{dl}$. Berdasarkan hasil penelitian diketahui distribusi pemberian SF dan jus jambu biji merah terhadap peningkatan hb pada remaja puteri di SMP negeri 19 Kota Jambi tahun 2019 responden dapat dilihat pada tabel 3.

Tabel 3. Distribusi responden berdasarkan Kadar Hemoglobin Sebelum Pemberian SF dan jus jambu biji merah terhadap peningkatan HB pada remaja puteri di SMP negeri 19 Kota Jambi tahun $2019 \mathrm{n}=74$

\begin{tabular}{clccc}
\hline \multirow{2}{*}{ No } & \multirow{2}{*}{ Kadar HB } & \multicolumn{2}{c}{ Distribusi } & \multirow{2}{*}{ Mean } \\
\cline { 3 - 4 } & & $\boldsymbol{F}$ & $\boldsymbol{\%}$ & \\
\hline 1 & $\geq 12.0 \mathrm{~g} / \mathrm{dL}$ & 41 & 55.4 & 11.94 \\
2 & $<12.0 \mathrm{~g} / \mathrm{dL}$ & 33 & 44.6 & \\
& Jumlah & $\mathbf{7 4}$ & $\mathbf{1 0 0 . 0}$ & \\
\hline
\end{tabular}

Berdasarkan tabel diatas dapat diketahui bahwa sebelum melakukan pemberian SF dan jus jambu biji merah masih banyak remaja dengan kadar hemoglobin $<12.0 \mathrm{~g} / \mathrm{dl}$ yaitu 33 responden (44.6\%) dengan rata-rata kadar hemoglobin remaja puteri adalah 11.94.

Berdasarkan hasil penelitian diketahui distribusi kadar hemoglobin setelah intervensi konsumsi SF dan Jus jambu biji merah pada remaja putri SMP negeri 19 Kota Jambi tahun 2019 dapat dilihat pada tabel 4.
Tabel 4. Distribusi Responden Berdasarkan Kadar Hemoglobin Setelah konsumsi SF dan jus Jambu Biji Merah SMP negeri 19 Kota Jambi tahun 2019 n=74

\begin{tabular}{|c|c|c|c|}
\hline \multirow[t]{2}{*}{ No } & \multirow{2}{*}{$\begin{array}{c}\text { Kadar Hb } \\
(\mathrm{g} / \mathrm{dl})\end{array}$} & \multicolumn{2}{|c|}{ Distribusi Frekuensi } \\
\hline & & $\mathbf{f}$ & $(\%)$ \\
\hline 1 & 11.3 & 1 & 1.4 \\
\hline 2 & 11.4 & 1 & 1.4 \\
\hline 3 & 11.5 & 4 & 5.4 \\
\hline 4 & 11.6 & 2 & 2.7 \\
\hline 5 & 11.9 & 1 & 1.4 \\
\hline 6 & 12.0 & 1 & 1.4 \\
\hline 7 & 12.1 & 1 & 1.4 \\
\hline 8 & 12.4 & 6 & 8.1 \\
\hline 9 & 12.5 & 5 & 6.8 \\
\hline 10 & 12.6 & 3 & 4.1 \\
\hline 11 & 12.7 & 2 & 2.7 \\
\hline 12 & 12.9 & 2 & 2.7 \\
\hline 13 & 13.1 & 5 & 6.8 \\
\hline 14 & 13.2 & 4 & 5.4 \\
\hline 15 & 13.4 & 11 & 14.9 \\
\hline 16 & 13.5 & 6 & 8.1 \\
\hline 17 & 13.6 & 2 & 2.7 \\
\hline 18 & 13.7 & 1 & 1.4 \\
\hline 19 & 13.9 & 1 & 1.4 \\
\hline 20 & 14.1 & 3 & 4.1 \\
\hline 21 & 14.2 & 2 & 2.7 \\
\hline 22 & 14.3 & 1 & 1.4 \\
\hline 23 & 14.4 & 1 & 1.4 \\
\hline 24 & 14.5 & 4 & 5.4 \\
\hline 25 & 14.6 & 1 & 1.4 \\
\hline 26 & 14.8 & 1 & 1.4 \\
\hline 27 & 15.1 & 1 & 1.4 \\
\hline 28 & 16.1 & 1 & 1.4 \\
\hline & Jumlah & 74 & 100.0 \\
\hline & Rata-rata & 13.15 & \\
\hline
\end{tabular}

Berdasarkan tabel diatas kadar hemoglobin setelah konsumsi jus guava paling rendah yaitu $11.3 \mathrm{~g} / \mathrm{dl}$ dan tertinggi $16.1 \mathrm{~g} / \mathrm{dl}$. Nilai rata-rata kadar hemoglobin remaja puteri sebelum diberikan jus guava adalah 13.15 $\mathrm{g} / \mathrm{dl}$. Berdasarkan hasil penelitian diketahui distribusi pemberian SF dan jus jambu biji merah terhadap peningkatan hb pada remaja puteri di SMP negeri 19 Kota Jambi tahun 2019 responden dapat dilihat pada tabel 5.

Tabel 5. Distribusi responden berdasarkan Kadar Hemoglobin Setelah Pemberian SF dan jus jambu biji merah terhadap peningkatan HB pada remaja puteri di SMP negeri 19 Kota Jambi tahun 2019 n=74

\begin{tabular}{ccccc}
\hline \multirow{2}{*}{ No } & Kadar HB & \multicolumn{2}{c}{ Distribusi } & \multirow{2}{*}{ Mean } \\
\cline { 3 - 4 } & & $\boldsymbol{f}$ & $\mathbf{\%}$ & \\
\hline 1 & $\geq 12.0 \mathrm{~g} / \mathrm{dL}$ & 65 & 87.8 & 13.15 \\
2 & $<12.0 \mathrm{~g} / \mathrm{dL}$ & 9 & 12.2 & \\
& Jumlah & $\mathbf{7 4}$ & $\mathbf{1 0 0 . 0}$ & \\
\hline
\end{tabular}

Berdasarkan tabel diatas dapat diketahui bahwa setelah melakukan pemberian SF dan jus jambu biji sebagian besar remaja puteri mengalami peningkatan kadar HB sehingga remaja puteri yang memiliki kadar 
Lia Artika Sari et al, Pengaruh Konsumsi SF dan Jus Jambu Biji Merah terhadap Perubahan Kadar Hemoglobin pada Remaja Puteri yang Mendapat Suplementasi Tablet SF di SMP Negeri 19 Kota Jambi Tahun 2019

$\mathrm{HB}<12.0 \mathrm{~g} / \mathrm{l}$ hanya 9 orang $(12.2 \%)$ dengan rata-rata kadar hemoglobin remaja puteri adalah 13.15.

\section{Analisis Bivariat \\ Pengaruh pemberian SF dan jus jambu biji merah terhadap peningkatan $\mathrm{HB}$ pada remaja puteri di SMP negeri 19 Kota Jambi tahun 2019}

Berdasarkan hasil penelitian diketahui distribusi pengaruh pemberian SF dan jus jambu biji merah terhadap peningkatan HB pada remaja puteri di SMP negeri 19 Kota Jambi tahun 2019 responden dapat dilihat pada tabel 6.

Tabel 6. Pengaruh Pemberian SF dan Jus Jambu Biji Merah Terhadap Peningkatan HB Pada Remaja Puteri di SMP negeri 19 Kota Jambi tahun 2019 n=74

\begin{tabular}{|c|c|c|c|c|c|c|c|c|}
\hline \multirow{3}{*}{ No } & \multirow{3}{*}{$\begin{array}{c}\text { Pemberian SF dan } \\
\text { Jus Jambu }\end{array}$} & \multicolumn{6}{|c|}{ Kadar HB } & \multirow{3}{*}{ p-value } \\
\hline & & \multicolumn{2}{|c|}{$\geq 12.0 \mathrm{~g} / \mathrm{dL}$} & \multicolumn{2}{|c|}{$<12.0 \mathrm{~g} / \mathrm{dL}$} & \multirow{2}{*}{$\mathbf{n}$} & \multirow{2}{*}{$\%$} & \\
\hline & & $\mathbf{n}$ & $\%$ & $\mathbf{n}$ & $\%$ & & & \\
\hline 1. & Setelah & 65 & 61.3 & 9 & 21.4 & 74 & 50.0 & \\
\hline \multirow[t]{2}{*}{2} & Sebelum & 41 & 38.7 & 33 & 78.6 & 74 & 50.0 & 0.000 \\
\hline & Jumlah & 106 & 100 & 42 & 100 & 148 & 100 & \\
\hline
\end{tabular}

Berdasarkan tabel diatas diketahui bahwa sebelum melakukan pemberian SF dan jus jambu biji merah dari 74 remaja puteri terdapat 33 remeja puteri $(78.4 \%)$ yang memiliki $\mathrm{HB}<12.0 \mathrm{~g} / \mathrm{dL}$ dan setelah mengkonsumsi SF dan jus jambu biji merah selama 7 hari kadar hemoglobin remaja puteri mengalami peningkatan menjadi $9(21.4 \%)$ yang memiliki HB $<12.0 \mathrm{~g} / \mathrm{dL}$. Secara statistik ada perbedaan yang signifikan dengan nilai sig (2-tailed) hitung $0.000<0.05$ maka dapat disimpulkan bahwa terdapat Pengaruh yang signifikan antara pemberian SF dan jus jambu biji merah terhadap peningkatan HB pada remaja puteri di SMP negeri 19 Kota Jambi tahun 2019.

\section{Pembahasan \\ Gambran pemberian SF dan jus jambu biji merah terhadap peningkatan HB pada remaja puteri di SMP negeri 19 Kota Jambi tahun 2019}

Berdasarkan hasil penelitian dapat diketahui bahwa sebelum melakukan pemberian SF dan jus jambu biji merah masih banyak remaja dengan kadar hemoglobin <12.0 g/dl dengan skor rata-rata kadar hemoglobin remaja puteri adalah 11.94 dan setelah pemberian SF dan jus jambu biji merah sebagian besar remaja puteri mengalami peningkatan kadar HB sehingga remaja puteri yang memiliki kadar $\mathrm{HB}<12.0$ g/l dengan skor rata-rata kadar hemoglobin remaja puteri adalah 13.15 .

Pada keadaan perdarahan berlebihan atau perdarahan normal pada haid, kehilangan besi akibat perdarahan harus diganti. Karena haid rata-rata mengeluarkan darah $60 \mathrm{ml}$ per bulan, yang sama dengan $30 \mathrm{mg}$ besi, perempuan memerlukan satu ekstra miligram per hari untuk diserap agar keseimbangan terjaga (Kemenkes, 2016). Suplemen zat 8 besi sebaiknya dikonsumsi pada malam hari, karena efek dari suplemen zat besi tersebut dapat menimbulkan rasa mual. Jumlah suplemen yang diberikan diperkirakan dapat memenuhi kebutuhan wanita. Kebutuhan akan zat besi $3000 \mathrm{~s} / \mathrm{d} 5000 \mathrm{mg}$ yang ada dalam tubuh, yang diekskresikan tubuh setiap harinya.

Banyak remaja puteri yang sering melewatkan dua kali waktu makan dan lebih memilih kudapan. Padahal sebagian besar kudapan bukan hanya hampa kalori, tetapi juga sedikit sekali mengandung zat gizi, selain dapat mengganggu (menghilangkan) nafsu makan. Selain itu remaja khususnya remaja puteri semakin menggemari junk food yang sangat sedikit (bahkan ada yang tidak ada sama sekali) kandungan kalsium, besi, riboflavin, asam folat, vitamin A dan vitamin.

Kadar hemoglobin remaja puteri meningkat juga dipengaruhi oleh makanan yang dikonsumsi remaja puteri setiap harinya, dimana pola konsumsi makan sehari - hari sebagian besar makan tiga (3) kali sehari dimana remaja puteri yang konsumsi makanan yang banyak mengandung zat besi seperti mengkonsumsi jenis sayuran misalnya sayuran hijau, kacang kacangan, kentang dan serealia serta beberapa jenis buah-buahan. Tidak menjaga pola makan atau makan yang tidak teratur akan mempengaruhi tingkat asupan makan atau zat gisi yang perlukan oleh tubuh untuk pertumbuhan bagi remaja.

\section{Pengaruh pemberian SF dan jus jambu biji merah terhadap peningkatan $\mathrm{HB}$ pada remaja puteri di SMP negeri 19 Kota Jambi tahun 2019}

Berdasarkan hasil penelitian diketahui bahwa sebelum melakukan pemberian SF dan jus jambu biji merah setelah mengkonsumsi SF dan jus jambu biji merah selama 7 hari kadar hemoglobin remaja puteri mengalami peningkatan. Secara statistik ada perbedaan yang signifikan dengan nilai sig (2-tailed) hitung $0.000<$ 0.05 maka dapat disimpulkan bahwa terdapat Pengaruh yang signifikan antara pemberian SF dan jus jambu biji merah terhadap peningkatan HB pada remaja puteri di SMP negeri 19 Kota Jambi tahun 2019.

Menurut hasil penelitian ini sejalan dengan penelitian Rusdi (2017) dimana pengaruh pemberian jus jambu biji merah (Psidium Guajava.L) Terhadap Kadar 
Lia Artika Sari et al, Pengaruh Konsumsi SF dan Jus Jambu Biji Merah terhadap Perubahan Kadar Hemoglobin pada Remaja Puteri yang Mendapat Suplementasi Tablet SF di SMP Negeri 19 Kota Jambi Tahun 2019

Hemoglobin. Hasil uji statistik didapatkan ada pegaruh pemberian jus jambu biji merah terhadap kadar hemoglobin dan ferritin serum penderita anemia remaja puteri dimana nilai $\mathrm{p}$ value $=<0,001$.

Menurut hasil penelitian Barirah (2017) perbedaan pengaruh suplemen jus jambu merah dengan jus buah naga merah untuk meningkatkan kadar hemoglobin Hasil dari studi Selama 7 hari pengobatan menunjukkan dalam intervensi kadar hemoglobin kelompok jus buah jambu merah meningkat sebesar 2,45 gr / dl. Pada kelompok intervensi jus buah naga merah adalah $1,44 \mathrm{gr}$ / dl sedangkan kelompok kontrol adalah 0,79 gr / dl. Dengan nilai p $0,000<\alpha(0,05)$ yang berarti ada perbedaan yang signifikan.

Hasil penelitian Yuniasih (2018) Pengaruh jus jambu biji merah dengan kadar hemoglobin pada remaja Putri Usia 13-16 Tahun. Hasil studi tingkat hemoglobin rata-rata sebelum pengobatan adalah 10,921gr / dl, dan kelompok kontrol adalah $11,450 \mathrm{~g} / \mathrm{dl}$. Setelah perlakuan campuran jus kacang hijau dan jambu biji pada kelompok perlakuan adalah 12,586gr / dl, sedangkan kelompok kontrol yang tidak diobati adalah $13,371 \mathrm{~g} / \mathrm{dl}$. Ada efek yang signifikan baik untuk kelompok perlakuan dan kontrol dalam pengiriman campuran jus kacang hijau dan jambu biji terhadap hemoglobin.

Hasil penelitian Krishnapillai (2013) Fe dari makanan yang dimodifikasi, dibandingkan dengan makanan biasa, secara signifikan $(\mathrm{P}<0,05)$ lebih besar pada kedua anak perempuan dan anak laki-laki. Penyerapan seng pecahan serupa antara makanan biasa dan dimodifikasi pada kedua jenis kelamin. Hepcidin ditemukan menjadi prediktor signifikan penyerapan besi dari dosis referensi.

Menurut asumsi peneliti Pemberian tablet $\mathrm{Fe}$ tanpa dukungan yang lain Nutrisi akan mempengaruhi tingkat penyerapan zat besi sehingga biovabilitas lebih rendah dibandingkan dengan pemberian $\mathrm{Fe}$ tablet bersama dengan jus buah jambu biji merah. Jadi yang tertinggi perubahan kadar hemoglobin pada kelompok jus buah jambu biji. Saran untuk tempat penelitian ini adalah jus jambu biji dapat digunakan sebagai upaya untuk mencegah terjadinya anemia kekurangan zat besi di remaja sebagai proses persiapan kehamilan dan persalinan.

\section{SIMPULAN}

1. Nilai rata-rata kadar hemoglobin pada Remaja Puteri sebelum mengkonsumsi SF dan jus jambu biji merah di SMP 19 Kota Jambi Tahun 2019 adalah $11.94 \mathrm{~g} / \mathrm{dl}$

2. Nilai rata- rata kadar hemoglobin pada Remaja Puteri sesudah mengkonsumsi SF dan jambu biji merah di SMP 19 Kota Jambi Tahun 2019 adalah $13.15 \mathrm{~g} / \mathrm{dl}$

3. Ada pengaruh mengkonsumsi SF dan jus jambu biji terhadap kadar hemoglobin remaja puteri di SMP 19 Kota Jambi Tahun 2019 dengan nilai sig (2-tailed) hitung $0.000<0.05$.

\section{DAFTAR PUSTAKA}

Afrianti, 2010. 33 macam buah-buahan untuk kesehatan. ALFABETA. Bandung: viii+ $184 \mathrm{hlm}$.

Almatsier, 2009. Prinsip dasar ilmu gizi. PT Gramedia pustaka utama. Jakarta.

Barirah, 2017. Pengaruh suplemen jus jambu merah dengan jus buah naga merah untuk meningkatkan kadar hemoglobin. Jurnal Kebidanan VOI 2 No 2

Cakrawati, 2012. Bahan pangan, gizi, dan kesehatan. ALFABETA. Bandung: $\mathrm{x}+234 \mathrm{hlm}$.

Dapartemen Gizi dan Kesehatan Masyarakat, 2014. Gizi dan kesehatan masyarakat. Jakarta: xviii +342 hlm.

Dieny. F. F, 2014. Permasalah gizi pada remaja putri. Penerbit Graha Ilmu Yogyakarta: viii +174

Gibney, 2008. Public health nutrition. EGC. Jakarta: xvi+467 hlm.

Hadiati, Apriyanti, 2015. Bertanam jambu biji di pekarangan. AgriFlo. Jakarta: vi+ $144 \mathrm{hlm}$.

Kemenkes RI, 2016. Pedoman pencegahan dan penanggulangan anemia pada remaja putri dan wanita usia subur. Jakarta: i $+61 \mathrm{hlm}$.

Kemenkes RI. 2013. Riset Kesehatan Dasar; RISKESDAS. Jakarta: Balitbang Kemenkes RI

Kementrian Kesehatan RI. 2018. Riset Kesehatan Dasar. Jakarta: Kemenkes RI

Krishnapillai, 2013. Inclusion Of Guava Enhances NonHeme Iron Bioavailability But Not Fractional Zinc Absorption From A Rice-Based Meal In Adolescents. The Journal of Nutrition. First published ahead of print April 17, 2013 as doi: 10.3945/jn.112.171702.

Morgan, 2009. Obstetri \& ginekologi panduan praktik. EGC. Jakarta: xvi+561 hlm.

Pratiwi, Eka, 2015. Faktor-Faktor Yang Mempengaruhi Anemia Pada Siswi Mts Ciwandan. Skripsi. Ilmu Kesehatan \& Kedokteran. UIN Syarifah Hidayatullah.

Rusdi (2017) dimana pengaruh pemberian jus jambu biji merah (Psidium Guajava.L) Terhadap Kadar Hemoglobin. Jurnal KEbidanan Vol 7 No 23

Sibagariang EE. Kesehatan Reproduksi Wanita-Edisi Revisi. Jakarta Trans Info Media. 2016;

Surahman et. all. 2016. Metodologi Penelitian. ttp: Kementrian Kesehatan Republik Indonesia.

WHO. 2001. Iron Deficiency Anemia Assessment, Prevention, and Control: Aguide For Programme Managers. Geneva : WHO.

World Health Organization. The World Medicine Situation 2011 3ed. Rational Use of Medicine. Geneva, 2011.

Yuniasih (2018). Pengaruh jus jambu biji merah dengan kadar hemoglobin pada remaja Putri Usia 13-16 Tahun. Jurnal Kebidanan Ternational Journal Of Scientific \& Technology Research Volume 7, Issue 1, January 2018 
Lia Artika Sari et al, Pengaruh Konsumsi SF dan Jus Jambu Biji Merah terhadap Perubahan Kadar Hemoglobin pada Remaja Puteri yang Mendapat Suplementasi Tablet SF di SMP Negeri 19 Kota Jambi Tahun 2019

Yusnaini. 2014. Pengaruh Konsumsi Jambu Biji (Psidium Guajava.L) Terhadap Perubahan Kadar Hemoglobin Pada Ibu Hamil Anemia Yang Mendapat Suplementasi Tablet Fe (Studi Kasus Ibu Hamil di Wilayah Kerja Puskesmas Kecamatan Indrapuri Kabupaten Aceh Besar Propinsi Aceh). Tesis Program Pascasarjana Undip. 